\author{
ZuZanna Kowalska, Filip Pniewski, Adam Latąa \\ Instytut Oceanografii \\ Wydziat Oceanografii $i$ Geografii \\ Uniwersytet Gdański \\ M. Piłsudskiego 46, 81-378 Gdynia \\ E-mail: zuzannakowalska0@gmail.com
}

\title{
KODY KRESKOWE DNA - MOŻLIWOŚCI I ZASTOSOWANIE
}

\section{WSTEP}

Paul Hebert w 2003 r. opracowal nowe podejście do identyfikacji gatunków wykorzystujac informację genetyczna zawarta w ich DNA. Jego metoda zakładała, że każdy organizm żywy ma w swoim genomie fragment, który może zostać wykorzystany jako swoisty znacznik. Technika nazwana barkodingiem DNA była odpowiedzia na problemy zwiazane $z$ oznaczaniem taksonów na podstawie cech morfologicznych, których analiza wymaga specjalistycznej wiedzy i ogromnego nakładu pracy oraz nie jest we wszystkich rozważanych przypadkach skuteczna (np. analizie poddawany jest fragment organizmu lub analizowany osobnik jest gatunkiem kryptycznym, nieznanym, bacdź wykazywał cechy pleomorficzne) (HEBERT i współaut. 2003). Barkoding DNA $z$ założenia miał być technika łatwa w zastosowaniu, szybka, standardowa $\mathrm{w}$ skali globalnej i wiarygodna. Bardzo szybko stał się metodą wspierajaca klasyczne podejście do taksonomii (SCHMIDT i współaut. 2015, TIZARD i współaut. 2019). Rozwój referencyjnych baz danych, zawierajacych sekwencje identyfikujace taksony sprawił, że inicjatywa ta ma charakter globalny i umożliwia dostęp i porównywanie otrzymanych barkodów DNA badaczom $z$ całego świata (RATNASINGHAM i HEBERT 2007). Obecnie główną baza danych zawierajaca sekwencje barkodów DNA jest BoLD (ang. The Barcode of Life Data System). Baza ta jest inicjatywa pomagajaca $\mathrm{w}$ pozyskiwaniu, przechowywaniu i analizowaniu rekordów barkodów DNA wszystkim zainteresowanym naukowcom (RATNASINGHAM i HEBERT 2007).
Celem niniejszej pracy jest podsumowanie możliwości stosowania kodów kreskowych DNA jako uniwersalnego narzędzia stosowanego w tak różnych dziedzinach jak: handel, przemysł, medycyna czy nauka (Ryc. 1).

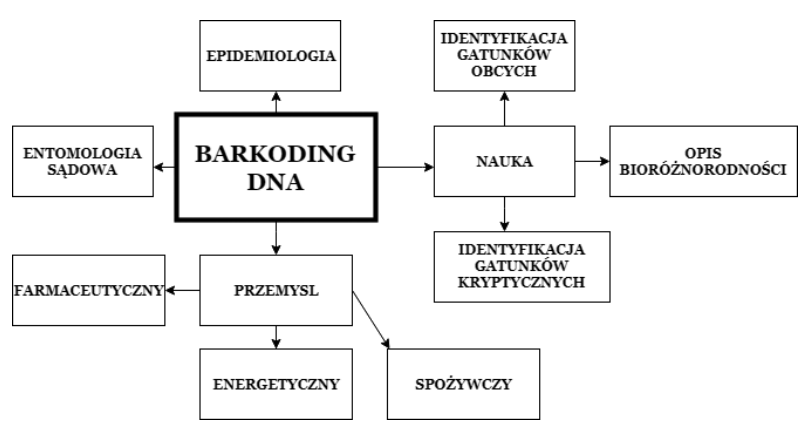

Rysunek 1. Możliwości zastosowania barkodingu DNA.

\section{POZNANIE I OPIS \\ BIORÓŻNORODNOŚCI ŚWIATA ORGANIZMÓW}

Wielu badaczy $z$ całego świata zajmuje się katalogowaniem organizmów występujących w środowisku. W wyniku licznych badań naukowych liczba znanych gatunków roślin czy zwierzat rośnie. Badacze chca wiedzieć jakie taksony występuja w środowisku oraz jak ich obecność może wpływać na funkcjonowanie ekosystemów. Badania zajmujące się różnorodnościa biologiczna maja swoje praktyczne zastosowanie. W przypadku dużych inwestycji, jak np. budowa portów, akwakultur czy elektrowni wiatrowych, 
niezbędne jest wykonanie analizy dotyczacej stanu środowiska, gatunków obecnych w ekosystemie oraz oceny wplywu inwestycji na bioróżnorodność gatunkową (BULL i współaut. 2016, KORSTIAN i współaut. 2016). Często takie analizy wykonywane sa przy użyciu mikroskopii świetlnej, w oparciu o klucze do oznaczania, oraz obserwacje większych organizmów. Nowoczesne podejście oparte o cechy molekularne gatunków wydaje się być sposobem bardziej wiarygodnym i zdecydowanie szybszym. Obecnie rozwijaja się nowe techniki sekwencjonowania (Sekwencjonowanie Nowej Generacji; ang. Next Generation Sequencing, NGS), które można wykorzystać do opisu różnorodności biologicznej $\mathrm{w}$ próbach środowiskowych (HAJIBABAEI i współaut. 2011). Bezpośrednia izolacja materiału genetycznego ze środowiska nie wymaga oględzin morfologicznych. Organizmy sa rozpoznawane na podstawie nie tylko obecności w próbie, ale również „śladów" DNA, które zostawily w osadzie, wodzie czy powietrzu.

\section{IDENTYFIKACJA GATUNKÓW OBCYCH I KRYPTYCZNYCH}

Co może się stać, gdy w środowisku pojawia się organizmy, które naturalnie $\mathrm{w}$ nim nie występują? Czy ekosystem jest na tyle elastyczny, aby poradzić sobie $z$ zaistniała zmianą? Czy środowisko ulegnie zmianom i przekształceniom? W przeszłości góry i oceany stanowily swoistego rodzaju barierę dla większości gatunków, dzięki czemu rożne ekosystemy mogły ewoluować we względnej izolacji, ale migracje ludności przyniosły wiele zamierzonych i niezamierzonych introdukcji. Ludzie wprowadzali nowe gatunki, aby zaspokoić swoje potrzeby fizjologiczne i społeczne (BAX i współaut. 2003, PIMENTEL i współaut. 2005). Introdukowane były zarówno rośliny, jaki i zwierzęta. Mimo wszystko częstotliwość takich działań była niewielka $\mathrm{w}$ porównaniu $\mathrm{z}$ dzisiejszymi, które spowodowane sa żegluga morska o charakterze handlowym czy turystycznym (BAX i współaut. 2003).

Gatunki inwazyjne transformuja $m$. in. środowisko morskie. Najbardziej „szkodliwe” moga wypierać gatunki rodzime, zmieniając strukturę zbiorowisk oraz sieć troficzna, a później podstawowe procesy, takie jak sedymentacja czy obieg materii (CLAVERO i GARCÍA-BERTHOU 2005). Inwazje gatunków sa głównym zagrożeniem dla bioróżnorodności i moga nieść za soba skutki ekologiczne i ekonomiczne. Następstwa inwazji moga być widoczne lokalnie, ale także moga być odczuwane w skali globalnej (MOLNAR i współaut. 2008). Bezpieczeństwo biologiczne staje się jednym $z$ ważniejszych problemów międzynarodowych, bowiem wiaże się to $z$ ryzykiem chorób zakaźnych przenoszonych przez gatunki obce (ARMSTRONG i BALL 2005), jak w przypadku karalucha Periplaneta japonica odnotowanego w Nowym Yorku. Zwierzęta te obniżaja jakość powietrza w pomieszczeniach przez uwalnianie substancji chemicznych (uważanych za alergeny), które wywołują astmę, a także alergie. Łączone sa również z licznymi patogenami, jak np. Klebsiella pneumoniae (EvANGELISTA i współaut. 2013), mogacymi powodować zapalenie płuc, zakażenia w obrębie kości, stawów, przewodu pokarmowego czy układu moczowego, prowadzac $\mathrm{w}$ drastycznych przypadkach do sepsy (VIRELla 2000). Takson ten jest trudny do odróżnienia od gatunku rodzimego; dopiero identyfikacja na poziomie molekularnym potwierdziła przypuszczenia o inwazji Periplaneta japonica, a także była wskazówka do sposobu wyeliminowania szkodnika, który ze względu na odporność na wysokie i niskie temperatury jest trudny do zwalczenia. Techniki molekularne sa wartościowym narzędziem, umożliwiajacym wczesna identyfikację organizmów inwazyjnych w środowisku.

Taksonomiczne wyzwanie stwarzaja również gatunki kryptyczne, które pomimo bariery rozrodczej są bardzo trudne do rozróżnienia morfologicznie, nawet dla doświadczonego taksonoma (BICKFORD i współaut. 2007). Identyfikacja gatunków kryptycznych jest ważna pod względem praktycznym, zdrowotnym, ekonomicznym oraz oczywiście poznawczym. Błędne przypisanie gatunku może przynosić poważne problemy w wielu aspektach życia człowieka czy przemyśle, jak np. w leczeniu chorób wywołanych pasożytami i wirusami, w zarządzaniu rybołówstwem czy zwalczaniu szkodników (BICKFORD i współaut. 2007).

Identyfikacja gatunków zwierząt i roślin ma dla nauk biologicznych kluczowe znaczenie. Wielu organizmów nie można przypisać do gatunku ze względu na ich niewielkie rozmiary, brak charakterystycznych cech morfologicznych czy ze względu na złożony cykl życiowy, lub też dlatego, że analizie poddawany jest jedynie fragment tkanek badanego organizmu (HEBERT i GREGORY 2005). Technika barkodingu DNA radzi sobie ze wszystkimi tymi problemami, dajac $\mathrm{w}$ wielu przypadkach jednoznaczny wynik w krótkim czasie. U roślin standardowe kodowanie kreskowe DNA polega na stosowaniu różnych kombinacji od jednego do czterech plastydowych regionów DNA (rbcL, matK, trnH-psbA, trnL) i/lub regionu niekodującego DNA między genami podjednostek rybosomu (ITS) (MANZANilla i współaut. 2019). Pojawiaja się 
ponadto propozycje uniwersalnych markerów dla świata roślin, jak UPA (23S rRNA), które charakteryzuja się wysokim sukcesem amplifikacji i można je stosować u wszystkich fotoautotrofów (SHERWOOD i PRESTING 2007). Dodatkowo, standardowy marker COI dla świata zwierząt ułatwia poznanie ich bioróżnorodności (HEBERT i współaut. 2003).

\section{PRZEMYSŁ FARMACEUTYCZNY}

Rośliny lecznicze sa od tysięcy lat szeroko wykorzystywane na świecie przez różne cywilizacje. Stosowanie ziół było częścią kultury i religii dla wielu pokoleń (VELDMAN i współaut. 2014). Wytwarza się $z$ nich często produkty w postaci preparatów leczniczych, maści, suplementów diety i ziół np. w formie suszu (CHEN i współaut. 2009). Tradycyjna medycyna została skomercjalizowana w ciagu ostatnich lat, natomiast większość roślin leczniczych jest nadal zbierana $z$ dzikich upraw (VELDMAN i współaut. 2014). Uprawia się kilka popularnych gatunków roślin leczniczych, ale w większości krajow jest to tylko niewielki procent gatunków używanych w lekach ziołowych (VELDMAN i współaut. 2014). Surowce pozyskiwane $z$ upraw transportuje się do fabryk i przetwórni. Dokładność identyfikacji w momencie zbierania i przetwarzania roślin jest niezwykle ważna, ze względu na możliwość fałszowania wyników czy zastępowania surowców innymi (SCHORI i SHOWALTER 2011). W niektórych przypadkach zastapienie jednego gatunku innym może mieć minimalny wpływ na skuteczność produktu, podczas gdy w innych, korzystny wpływ może zostać całkowicie utracony. Co więcej, zastępowanie roślin w pewnych rodzinach (szczególnie Apiaceae i Solanaceae) może skutkować powstaniem alergii, zatruć lub stanowić śmiertelne zagrożenie dla osób stosujacych uzyskane $z$ nich preparaty czy suplementy (SCHORI i SHOWALTER 2011). Barkoding DNA jest już powszechnie stosowana techniką do ustalenia tożsamości roślin leczniczych, umożliwiajacca przemysłowi farmaceutycznemu zastosowanie znanych i skutecznych gatunków, nie narażając przy tym zdrowia i życia konsumentów.

\section{PRZEMYSŁ ENERGETYCZNY}

Globalna gospodarka wymaga stosowania kopalnych węglowodorów, od produkcji tworzyw sztucznych i nawozów, po dostarczanie energii potrzebnej do oświetlenia, ogrzewania $i$ transportu. Wraz $z$ rosnaca liczba ludności na świecie i rozwijająca się gospodarka następuje wzrost zużycia paliw kopalnych. Ponadto, dochodzi do wzrostu stężenia $\mathrm{CO}_{2}$ w atmosferze i możliwości znacznych zmian klimatu za pośrednictwem gazów cieplarnianych (HuGHES 2010). Wreszcie, ropa jest ograniczonym zasobem, który w końcu się wyczerpie lub stanie się zbyt drogi do odzyskania (HANNon i współaut. 2010). Czynniki te napędzają rozwój odnawialnych źródeł energii, które moga zastapić paliwa kopalne i umożliwiają większy dostęp do zasobów paliw dla wszystkich, a jednocześnie znacznie zmniejszają emisję dwutlenku węgla do atmosfery. Wiele technologii wykorzystujących odnawialne źródła energii zostało przetestowanych i chociaż żadna pojedyncza strategia nie zaspokoi całkowitego zapotrzebowania energetycznego, wydaje się, że można zastosować ich kombinację, która znacznie zmniejszy zależność ludzkości od paliw kopalnych (HANNON i współaut. 2010). Produkcja biopaliw jest jednym $z$ wielu pomysłów, zmierzających do ograniczenia zużycia ropy, chroniąc jednocześnie środowisko. Do produkcji takiego rodzaju paliwa wykorzystuje się przede wszystkim rośliny zarówno lacdowe, jak i morskie (BOROWITZKA i MoHEIMANI 2013). Glony wydaja się być lepszym surowcem chociażby $z$ tego względu, że uprawa roślin lądowych wymaga ogromnej powierzchni gruntów rolnych (HANNON i współaut. 2010). Produkcja zielonej energii z glonów wymaga dokładnego określenia ich gatunku oraz ustalenia zawartości lipidów w komórkach w różnych fazach hodowli (BoROWITZKA i MOHEIMANI 2013). Zanieczyszczenia hodowli masowych czynnikami biologicznymi sa głównym zagrożeniem w produkcji biopaliw (CARNEY i współaut. 2016). Skażenie organizmami eukariotycznymi i bakteryjnymi wpływa na zmniejszanie biomasy glonów. Określenie, jakie organizmy niepożądane występuja $\mathrm{w}$ bioreaktorach i jaki maja wpływ na proces produkcji jest kluczowym zadaniem, aby przedsięwzięcie było opłacalne (RADAKOVITS i współaut. 2010, CARNEY i współaut. 2016). Dlatego też stosuje się techniki oparte na DNA (w tym barkoding DNA) do identyfikacji taksonu, który zawiera dużo komórek tłuszczowych i będzie najlepszy do produkcji wysokoenergetycznego paliwa. Kodowanie kreskowe DNA stosuje się również do identyfikacji zanieczyszczeń czynnikami biologicznymi w hodowlach masowych.

\section{PRZEMYSŁ SPOŻYWCZY}

Surowce wysokiej jakości maja podstawowe znaczenie dla produkcji żywności o odpowiedniej wartości odżywczej i pożądanym smaku. Dla przemysłu spożywczego opracowano szereg procesów technologicznych i biotechnologicznych w celu zachowania i poprawy właściwości organoleptycznych 
produktów. Kontrole jakości są przeprowadzane za pomoca różnych testów laboratoryjnych, które stanowią obowiązkowy punkt wyjścia dla właściwego systemu sprawdzania produktów spożywczych. Zapotrzebowanie na niezawodne systemy kontrolowania składu żywności spowodowało utworzenie różnych analitycznych podejść do tego problemu (BOTTERO i DALMASSO 2011, FAJARDO i współaut. 2010, HELlBERG i MORRISEY 2011). Sprawdzenie autentyczności żywności polega głównie na analizie białek i/lub sekwencji DNA. Metody oparte na badaniu białek obejmuja testy immunologiczne, techniki elektroforetyczne i chromatograficzne. . Chociaż metody te sa skuteczne w testowaniu swieżych produktów to w przypadku analiz silnie przetworzonej żywności maja niska efektywność. W tych przypadkach techniki oparte na DNA sa bardziej skuteczne i moga być stosowane do różnych typów żywności (LOCKLEY i BARDSley 2000). Ponadto, DNA jest łatwe do izolowania i dzięki niemu można uzyskać więcej informacji dotyczacych składu i produkcji produktów spożywczych (HELlBERG i MORRISEY 2011).

Metody identyfikacji oparte na DNA pozwalaja na szybkie i ostateczne uwierzytelnianie przetworzonych produktów $z$ owoców morza pozbawionych charakterystycznych cech morfologicznych (np. filetów i produktów $z$ owoców morza). Wprowadzanie niecertyfikowanych produktów rybnych ( zastępowanie tańszymi zamiennikami) jest zgłaszane w wielu krajach i dotyczy różnych gatunków ryb, mięczaków czy skorupiaków (CARVALHO i współaut. 2015).

Dzięki najnowszym osiagnięciom w biologii molekularnej markery DNA stały się najbardziej skutecznym narzędziem w analizie DNA odmian roślin i ras zwierząt, a także sa wykorzystywane do sprawdzenia składu i jakości surowców w przemyśle spożywczym (MAFRA i współaut. 2008).

\section{EPIDEMIOLOGIA}

Ze względu na prostotę i wiarygodność technika barkodingu DNA znalazła zastosowanie w badaniach epidemiologicznych. Służy do wykrywania pasożytów, np. Blastocystis czy Schistosoma mansoni. Blastocystis należy do pasożytów jelitowych szerokiej gamy gatunków gospodarzy, w tym ludzi; jest niezwykle trudny do wytepienia i wyizolowania (UDONSOM i współaut. 2018). Ponadto, Blastocystis obejmuje liczne podtypy (prawdopodobnie gatunki), $z$ których wiele zidentyfikowano dopiero niedawno, a molekularne badania epidemiologiczne ujawniły znacząca różnicę w rozmieszczeniu podtypów między gatunkami gospodarza i regionami geograficznymi (STENSVOLD 2013). Natomiast schistosomatoza jelitowa wywoływana przez Schistosoma mansoni stanowi poważny problem zdrowia publicznego w Afryce (STANDLEY i współaut. 2010).

Analiza za pomoca barkodingu DNA doprowadziła do znaczacego postępu w diagnostyce i badaniach Blastocystis i Schistosoma mansoni w ciagu ostatnich kilku lat, umożliwiając dokładna identyfikację i charakterystykę molekularną dzięki wysokiej sile różnicujacej. W identyfikacji podtypów wykorzystuje się geny małej podjednostki rybosomu (SSU) lub geny mitochondrialne kodujace oksydazę cytochromowa (COI) (SciclunA i współaut. 2006, STANDLEY i współaut. 2010). Amplifikacja regionu, a następnie sekwencjonowanie pojedynczego startera produktu PCR zapewnia wystarczajaca liczbę danych do jednoznacznego przypisania izolatów do określonych podtypów. Barkoding DNA może odpowiedzieć na pytania zwiazane $z$ drogami przenoszenia pasożyta oraz właściwościami różnych gatunków (SCICLUNA i współaut. 2006).

Wirus ptasiej grypy (H5N1) przenoszony jest przez żywe ptactwo, a choroba wywołana tym wirusem jest w dużym odsetku śmiertelna (CLAAS i współaut. 1998). Zakażenie następuje poprzez kontakt zdrowego osobnika (w tym człowieka), $z$ osobnikiem zakażonym. Ze względu na śmiertelność i łatwość zakażenia bardzo istotne jest rozwinięcie techniki identyfikacji nosicieli. Identyfikacja osobników opiera się na izolacji DNA $z$ próbek kału lub tkanek (LEE i współaut. 2010). Nie jest to technika inwazyjna, nie powoduje śmierci ptaka, natomiast jest w stanie stwierdzić, które $z$ badanych zwierząt sa nosicielami wirusa, co umożliwia kontrolę nad jego rozprzestrzenianiem i wykrywaniem ognisk chorobowych (LEE i współaut. 2010).

\section{ENTOMOLOGIA SĄDOWA}

Według Międzynarodowej Unii Ochrony Przyrody (IUCN), obecny wskaźnik wymierania gatunków jest 1000 razy większy od oczekiwanego. To dramatyczne zjawisko ma wiele przyczyn, warto jednak zauważyć, że utrata różnorodności biologicznej powodowana jest przede wszystkim działalnościa człowieka (ROLO i współaut. 2013). W ostatnich latach entomologia kryminalistyczna jest stosowana między innymi $\mathrm{w}$ przestępstwach związanych $\mathrm{z}$ nielegalnym kłusownictwem, handlem i posiadaniem gatunków chronionych, a także okrucieństwem wobec zwierzat i ludzi (Rolo i współaut. 2013). Owady i ich larwy dostarczaja informacji o czasie zgonu czy przenoszeniu zwłok. Znajomość gatunku i jego morfologii oraz czasu trwania poszcze- 
gólnych etapów rozwojowych muchy jest kluczowa w ocenie kryminalistycznej (DRABER-MOŃKO i współaut. 2009, MEIKLEJOHN i współaut. 2013). Pomimo znacznego potencjału kryminalistycznego, ich stosowanie jest ograniczone, ponieważ cechy morfologiczne tych owadów różnią się na każdym etapie ich życia (MEIKLEJOHN i współaut. 2013). Identyfikacja nekrofagicznych owadów $z$ rzędu Diptera tradycyjnie odbywała się na podstawie charakterystycznych cech budowy, jednak obecnie coraz powszechniej stosuje się barkoding DNA i uniwersalny dla wszystkich zwierzat marker COI (DRABER-MONKKO i współaut 2009, MEIKLEJOHN i współaut. 2013, ROLO i współaut. 2013). Kodowanie kreskowe DNA rozwiazuje problemy $z$ analizą cech morfologicznych owadów w różnych etapach rozwoju i sprawia, że obecność larw czy dorosłych osobników staje się wiarygodnym dowodem przestępstwa.

\section{PODSUMOWANIE}

Zalety barkodingu DNA takie jak: łatwość wykonania badań, szybkość otrzymania wyników i ich wiarygodność spowodowały, że narzędzie to ma szerokie zastosowanie nie tylko w dziedzinach nauki, ale również w przemyśle, medycynie, handlu czy sadownictwie. Analizowane sa fragmenty tkanek, ślady zwierząt i roślin, które sprawiają, że metoda ta nie jest szkodliwa dla organizmów żywych. Przedstawione zastosowania kodowania DNA pokazują, że narzędzie to jest uniwersalne i może być używane także w przypadkach, gdzie klasyczne analizy sa zbyt kosztowne, przestarzałe, mało wiarygodne, czasochłonne bądź wymagaja doświadczonych specjalistów. Wraz ze wzrostem zasobów informacji w bazach danych oraz rozwojem przemysłu, medycyny czy nauki, narzedzie to będzie coraz szerzej wykorzystywane i zdecydowanie ułatwi pracę wielu analitykom i naukowcom, a także poprawi jakość życia ludzi.

$$
\text { Streszczenie }
$$

Barkoding DNA jest technika, której celem jest ułatwienie identyfikacji wszystkich organizmów występujacych w przyrodzie. Wykorzystuje ona krótka sekwencję nukleotydów charakterystyczną dla danego organizmu jako jego znacznik i umożliwia określenie gatunku bądź rodzaju badanego organizmu, jego postaci larwalnej, czy materiału kopalnego. Kodowanie kreskowe DNA stało się technika molekularna wspierająca tradycyjne podejście do taksonomii, a także ze względu na łatwość stosowania, wiarygodność uzyskanych wyników posiada liczne zastosowania w różnych dziedzinach, które wydaja się ważne i ułatwiaja pracę czy życie ludzi. W artykule opisano możliwości i zalety wykorzystania techniki kodowania DNA w dziedzinach takich jak: nauka, przemysł, epidemiologia, entomologia sądowa, gdzie szybka analiza taksonomiczna jest niezwykle ważna. Technika ta posia- da liczne możliwości zastosowania a wraz $z$ rozwojem przemysłu i nauki stosowanie takich systemów diagnostyki taksonomicznej zyska większą popularność.

\section{LITERATURA}

ARMSTRONG K. F., BALL S. L., 2005. DNA barcodes for biosecurity: invasive species identification. Philosoph. Transact. Royal Soc. B: Biol. Sci. 360, 1813-1823.

Bax N., Williamson A., Aguero M., Gonzalez E., GEEVES W., 2003. Marine invasive alien species: a threat to global biodiversity. Marine Policy 27, 313-323.

BICKFORD D., LOHMAN D. J., SODHI N. S., NG P. K., MEIER R., WinkeR K., DAS I., 2007. Cryptic species as a window on diversity and conservation. Trends Ecol. Evol. 22, 148-155.

BorowitzKa M. A., Moheimani N. R., 2013. Algae for biofuels and energy. Springer, Dordrecht.

BotTero M. T., DALMAsso A., 2011. Animal species identification in food products: Evolution of biomolecular methods. Veterinary J. 190, 34-38.

Bull J. W., Jobstvogt N., BöhnKe-Henrichs A., Mascarenhas A., Sitas N., BaUlcomb C., CaRTER-SILK E., 2016. Strengths, weaknesses, opportunities and threats: A SWOT analysis of the ecosystem services framework. Ecosystem Services 17, 99-111.

Carney L. T., Wilkenfeld J. S., Lane P. D., SolBERG O. D., FuQuA Z. B., CORNElius N. G., LANE T. W., 2016. Pond crash forensics: presumptive identification of pond crash agents by next generation sequencing in replicate raceway mass cultures of Nannochloropsis salina. Algal Res. 17, 341-347.

CARVAlHo D. C., PAlHaRes R. M., DRummond M. G., FRIGO T. B., 2015. DNA Barcoding identification of commercialized seafood in South Brazil: A governmental regulatory forensic program. Food Control 50, 784-788.

Chen S., SONG J., YAO H., SHI L., LUO K., HAN J., 2009. Strategy and key technique of identification of Chinese herbal medicine using DNA barcoding. Chinese J. Nat. Med. 7, 322-327.

Claas E. C., Osterhaus A. D., Van Beek R., De JoNG J. C., RimmelzWAan G. F., Senne D. A., WEBSTER R. G., 1998. Human influenza A H5N1 virus related to a highly pathogenic avian influenza virus. Lancet 351, 472-477.

Clavero M., García-Berthou E., 2005. Invasive species are a leading cause of animal extinctions. Trends Ecol. Evol. 20, 110.

Draber-MońKO A., MALEWSKI T., POMORSKI J., ŁoŚ M., ŚLIPIŃSKI P., 2009. On the morphology and mitochondrial DNA barcoding of the flesh fly Sarcophaga (Liopygia) argyrostoma (Robineau-Desvoidy, 1830)(Diptera: Sarcophagidae) - an important species in forensic entomology. Annales Zoologici 59, 465-494.

EVANGELISTA D., BUSS L., WARE J. L., 2013. Using DNA barcodes to confirm the presence of a new invasive cockroach pest in New York City. J. Econom. Entomol. 106, 2275-2279.

FAJARDO V., GONZÁleZ I., ROJAS M., GARCía T., MARTÍN 'R., 2010. A review of current PCRbased methodologies for the authentication of meats from game animal species. Trends Food Sci. Technol. 21, 408-421.

Hajibabaei M., Shokralla S., ZhOU X., Singer G. A., BAIRD D. J., 2011. Environmental barcoding: a next-generation sequencing approach for biomonitoring applications using river benthos. PLoS One 6, e17497. 
HanNon M., Gimpel J., TRAN M., Rasala B., MaYFIELD S., 2010. Biofuels from algae: challenges and potential. Biofuels 1, 763-784.

HEBERT P. D., GREgORY T. R., 2005. The promise of DNA barcoding for taxonomy. System. Biol. 54, 852-859.

HEBERT P. D. CYwinska A, Ball S, L., DEWAaRD J. R., 2003. Biological identifications through DNA barcodes. Proc. Royal Soc. London Series B, Biol. Sci. 270, 313-321.

HellberG R. S. R., MORRISSEY M. T., 2011. Advances in DNA-based techniques for the detection of seafood species substitution on the commercial market. JALA: J. Assoc. Lab. Automat. $16,308-321$.

HuGHES L., 2000. Biological consequences of global warming: is the signal already apparent? Trends Ecol. Evol. 15, 56-61.

Korstian J. M., Hale A. M., BennetT V. J., WilLIAMS D. A., 2016. Using DNA barcoding to improve bat carcass identification at wind farms in the United States. Conserv. Genet. Resour. 8, 27-34.

LEE D. H., LeE H. J., LeE Y. J., KANG H. M., JEONG O. M., KIM M. C., PARK S. Y., 2010. DNA barcoding techniques for avian influenza virus surveillance in migratory bird habitats. J Wildlife Diseas. 46, 649-654.

LOCKLEY A. K., BARDSLEY R. G., 2000. DNA-based methods for food authentication. Trends Food Sci. Technol. 11, 67-77.

MAFRA I., FERREIRA I. M., OliveIrA M. B. P., 2008. Food authentication by PCR-based methods. Europ. Food Res. Technol. 227, 649-665.

Manzanilla V., Teixidor I. T., Martin G., HollingSWORTH P., KOOL A., 2019. Tracking the global supply chain of herbal medicines with novel genomic DNA barcodes. https://www.biorxiv. org/content/10.1101/744318v1.

Meiklejohn K. A., Wallman J. F., DowTON M., 2013. DNA barcoding identifies all immature life stages of a forensically important flesh fly (Diptera: Sarcophagidae). J. Forensic Sci. 58, 184-187.

MolnaR J. L., Gamboa R. L., Revenga C., SpalDING M. D., 2008. Assessing the global threat of invasive species to marine biodiversity. Front. Ecol. Environ. 6, 485-492.

Pimentel D., Zuniga R., MORRISON D., 2005. Update on the environmental and economic costs associated with alien-invasive species in the United States. Ecol. Econom. 52, 273-288.

RADAKOVITS R., JINKERSON R. E., DARZINS A. Posewitz M. C., 2010. Genetic engineering of algae for enhanced biofuel production. Eukaryotic Cell 9, 486-501

RATNASINGHAM S., HEBERT P. D., 2007. BOLD: The barcode of life data system. Mol. Ecol. Notes $7,355-364$.

Rolo E. A., Oliveira A. R., DOURAdo C. G., FARINHA A., REBELO M. T., DIAS D., 2013. Identification of sarcosaprophagous Diptera species through DNA barcoding in wildlife forensics. Forensic Sci. Int. 228, 160-164.

SCHMIDT S., SCHMID-EGGER C., MORINIËR J., HASZPRUNAR G., HEBERT P. D., 2015. DNA barcoding largely supports 250 years of classical taxonomy: identifications for $C$ entral $E$ uropean bees (H ymenoptera, A poidea partim). Mol. Ecol. Resour. 15, 985-1000.

SCHORI M., SHOWALTER A. M., 2011. DNA barcoding as a means for identifying medicinal plants of Pakistan. Pakistan J. Bot. 43, 1-4.

SCICluna S. M., TAWARI B., Clark C. G., 2006. DNA barcoding of Blastocystis. Protist 157, $77-85$

Sherwood A. R., Presting G. G., 2007. Universal primers amplify a 23S rDNA plastid marker in eucaryotic algae and cyanobacteria. J. Phycol. 43, 605-608.

Standley C. J., Kabatereine N. B., Lange C. N., LWAMBO N. J. S., STOTHARD J. R., 2010. Molecular epidemiology and phylogeography of Schistosoma mansoni around Lake Victoria. Parasitology 137, 1937-1949.

Stensvold C. R., 2013. Blastocystis: genetic diversity and molecular methods for diagnosis and epidemiology. Tropical Parasitol. 3, 26.

Tizard J., PATEl S., WAUGH J., TAVARES E., BERGMANN T., GILL B., BAKER A., 2019. DNA barcoding a unique avifauna: an important tool for evolution, systematics and conservation. BMC Evolut. Biol. 19, 52

UdONSOM R., PRASERTBUN R., MAHITTIKORN A., MORI H., ChangBunJong T., KOMAlamisRa C., POPRUK S., 2018. Blastocystis infection and subtype distribution in humans, cattle, goats, and pigs in central and western Thailand. Infect. Genet. Evol. 65, 107-111.

VELDMAN S., OtIENO J., GRAVENDEEL B., VAN ANDEL T., DE BOER H., 2014. Conservation of endangered wild harvested medicinal plants: use of DNA barcoding. Plant Bioresour Appl. Food Med. Cosmet. 81, 88

VIRELla G., 2000. Mikrobiologia i choroby zakaźne. Urban \& Partner, Wrocław, 181. 
KOSMOS Vol. 68, 4, 651-657, 2019

\author{
ZuZanna Kowalska, Filip Pniewski, Adam Lataza
}

Institute of Oceanography, University of Gdansk, 46 M. Piłsudskiego Str., 81-378 Gdynia, E-mail: zuzannakowalska0@gmail.com

DNA BARCODES - POSSIBILITIES AND APPLICATION

\title{
Summary
}

DNA barcoding is a technique which purpose is to facilitate the identification of all the organisms occurring in the world. It uses a short characteristic sequence for taxon and allows determining the species or type of the examined fragment of the organism, its larval form or fossil material. This technique has become a molecular tool supporting the traditional approach to taxonomy. Due to its efficienty and credibility of the obtained results, this technique has numerous applications in various fields. This work describes the possibilities and advantages of DNA barcoding in areas such as: science; industry; epidemiology; forensic entomology, where fast taxonomic analysis is extremely important. This technique has numerous applications. With the development of industry and science, the use of such taxonomic diagnostics systems will become more popular.

Key words: DNA barcodes, DNA barcoding, species identification 